\title{
ДОСЛІДЖЕННЯ ІННОВАЦІЙНО-ІНВЕСТИЦІЙНИХ УМОВ МОДЕРНІЗАЦІЇ ПІДПРИЕМСТВ ІНФРАСТРУКТУРНОЇ СФЕРИ
}

\section{RESEARCH OF INNOVATION AND INVESTMENT CONDITIONS OF MODERNIZATION OF INFRASTRUCTURE ENTERPRISES}

\author{
Вовк Ольга Миколаївна \\ кандидат економічних наук, доцент, \\ Національний авіаційний університет \\ ORCID: https://orcid.org/0000-0002-1680-1959 \\ Кривенко Вікторія Олександрівна \\ магістр, \\ Національний авіаційний університет \\ ORCID: https://orcid.org/0000-0001-5434-718X \\ Vovk Olha, Kryvenko Viktoria \\ National Aviation University
}

\begin{abstract}
У статті досліджено тенденції інвестиційної підтримки та модернізації підприємств інорраструктурної ссрери. Аналіз масштабів інвестування в модернізацію транспортних підприємств показав низьку активність щодо інноваційного оновлення. До основних умов інноваційно-інвестиційної підтримки модернізації підприємств інсрраструктурної сорери віднесено: непослідовність технологічної структуризації; соціальні диспропорції між доходами в державному і приватному секторах, окремих галузях; рефрормування державного сектору економіки за рахунок іноземного фрінансування; запровадження електронного інституційного регулювання; високі податкові ставки; регіонально-територіальна реформа. Основними векторами для модернізації інфраструктурної сорери є міжнародна інтеграція та нарощування відповідної конкурентоспроможності.
\end{abstract}

Ключові слова: модернізація, інновації, інвестиції, економічний розвиток, модернізація, підприємства інсрраструктурної ссрери, транспорт.

В статье исследованы тенденции инвестиционной поддержки и модернизации предприятий инфраструктурной ссреры. Анализ масштабов инвестирования в модернизацию транспортных предприятий показал низкую активность инновационного обновления. К основным условиям инновационно-инвестиционной поддержки модернизации предприятий инфраструктурной сферы отнесены: непоследовательность технологической структуризации; социальные диспропорции между доходами в государственном и частном секторах, отдельных отраслях; реформирования государственного сектора экономики за счет иностранного фринансирования; внедрение электронного институционального регулирования; высокие налоговые ставки; региональнотерриториальная реформа. Основными векторами для модернизации инфраструктурной сфреры являются международная интеграция и наращивание соответствующей конкурентоспособности.

Ключевые слова: модернизация, инновации, инвестиции, экономическое развитие, модернизация, предприятия инфрраструктурной сореры, транспорт.

The article investigated the conditions and patterns of investment support and the modernization of infrastructure enterprises. Infrastructure enterprises in modern conditions face new needs in ensuring competitiveness and safety, forming the quality of services, innovation, and efficiency. These challenges show that some problems remain unresolved in the transport industry that hinders its strategic development. The effectiveness of solving these problems is designed by the scale and efficiency of investment support for the modernization process and the availability of new innovative technologies. Thus, in the structure of investments in the national economic system in 2020, infrastructure enterprises account for only 10.8\%; Diagnostics of the objectivity of modernization has shown a steady trend of investing intangible assets ( $95 \%$ on average by industry), which indicates a low innovation and intellectual activity of modernization of enterprises. The analysis shows the technical and technological nature of modernization 
changes in infrastructure enterprises since only 33\% of investments are investments in the technical updating of machines and equipment. Thus, the main conditions for innovative and investment support for the modernization of infrastructure enterprises include inconsistency in technological structuring; social disparities between incomes in the public and private sectors and in certain sectors; technical direction of modernization and lack of effective innovative transformation of management technologies; reforming the public sector through foreign financing; the introduction of electronic institutional regulation; high tax rates; regional-territorial reform. Modernization should be a tool not only for technical updating and increasing profits, but also for systemic transformation of development processes in the enterprise, adaptation to changes in the environment, and increasing competitiveness in markets. The main vectors for the modernization of the infrastructure sphere are international integration and increasing the corresponding competitiveness.

Keywords: modernization, innovations, investments, economic development, modernization, enterprises of infrastructural sphere, transport.

Постановка проблеми Сучасні ринкові умови господарювання вимагають швидкої адаптації підприємств за рахунок впровадження модернізаційних змін у технології виробництва продукції та в управлінські процеси. Інфрраструктурна сорера України являє собою єдину систему, що включає усі види транспортних послуг та сектори ресурсозабезпечення, що $є$ має забезпечувати через транспортно-логістичну систему усі галузі національної економічної системи. Конкурентоспроможна та ефрективна трансорормація інфрраструктурної сорери вимагає інноваційноінвестиційної підтримки модернізаційних процесів, що спрямовується на орієнтири щодо підвищення якості послуг транспортного сектору в умовах глобалізованої інтеграції. Описані умови вимагають поглибленого аналізу тенденцій у інвестиційній діяльності та інноваційній активності, удосконалення системи модернізації транспортного комплексу.

Аналіз останніх досліджень і публікацій. Для детального вивчення теоретичних і практичних аспектів модернізаційної трансформації інфрраструктурного сектору в умовах інноваційності та міжнародної інтеграції, а також методологій аналізу осучаснення інфрраструктурної сорери, немало зусиль прикладали такі науковці, як Арефр'єва О.В., Бутко М.П., Валінкевич Н.В., Петрович Й.М., Тульчинська С.О., Кучерук Г.Ю. та ін. [1-6].

Виділення невирішених раніше частин загальної проблеми. Незважаючи на наявність наукових публікації з питань інноваційного та інвестиційного забезпечення процесів оновлення підприємств інфрраструктурної сорери недостатньо дослідженими залишаються проблеми ресурсно-технологічної підтримки модернізаційних процесів, а також потребують актуалізації сучасні закономірності, від яких залежать результати модернізації й конкурентоспроможність підприємств.

Формулювання цілей статті (постановка завдання). Метою наукової статті $€$ аналіз тен- денцій та фрормалізація закономірностей інноваційно-інвестиційного забезпечення модернізації підприємств інсрраструктурної ссрери.

Виклад основного матеріалу дослідження. Поштовхом до нового євроінтеграційного вектору розвитку України стали глобалізаційно-економічні процеси. Євроінтеграція офріційно проголошена першорядним пріоритетом зовнішньої політики України згідно 3 Законом України «Про внесення змін до Конституції України (щодо стратегічного курсу держави на набуття повноправного членства України в Європейському Союзі та в Організації Північноатлантичного договору)» [8]. Транспортний комплекс як всієї України, так і регіонально досить сильно відрізняється від світових стандартів і вимог, прийнятих Європейським Союзом, а транспортна інфрраструктура й машини значно не наздоганяє європейську із-за відсутності послідовного застосування інноваційно-інвестиційних стратегій загального розвитку та модернізації інфрраструктурної сорери та програми для кожного виду транспорту (рис. 1).

Національний транспортний комплекс України містить у собі різні види транспорту і за деякими показниками $є$ одним із найпотужніших серед європейських транспортних систем. Такими показниками виступають довжина шляхів з'єднання та обсяги вантажоі пасажирообігу. Для розуміння чіткої картини модернізації транспортного комплексу країни важливим моментом $€$ аналіз обсягів перевезених вантажів за видами транспорту, кількість перевезених пасажирів за видами транспорту, вантажообіг за видами транспорту й пасажирообіг за видами транспорту [9]. Результати діяльності транспортного комплексу інфрраструктурної сфрери протягом 2015-2019 років свідчать про наявність ознак зниження ділової активності підприємств одних сорер й підвищення ділової активності підприємств інших сорер (табл. 1). В даний час стан транспортної інсрраструктури не дозво- 


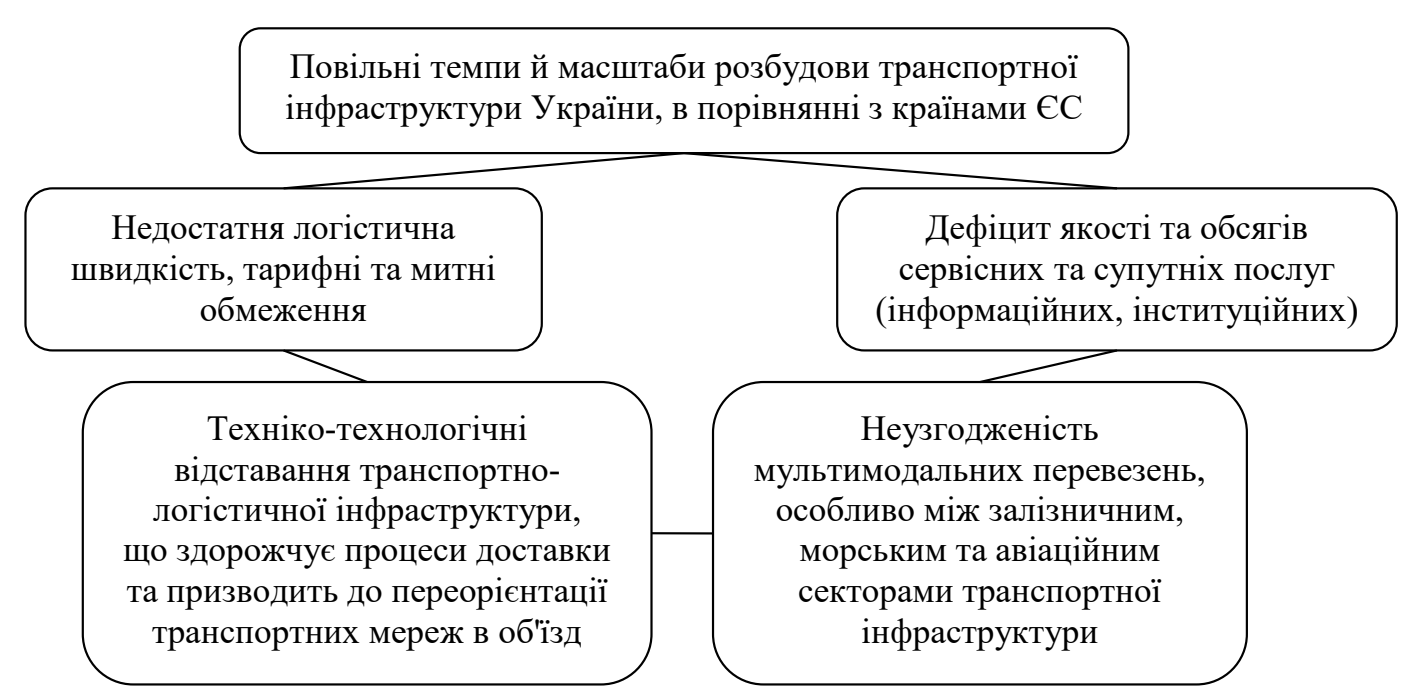

Рис. 1. Негативні тенденції інноваційно-інвестиційного забезпечення модернізації підприємств інфраструктурної сфери у вітчизняній економці

Джерело: узагальнено авторами

ляє в достатній мірі забезпечити потреби економічного розвитку країни та конкурентоспроможність міжнародних перевезень вантажів через українську територію. Це стосується всіх видів транспорту.

Проте, через хронічне недофрінансування інвестиційної активності модернізації дорожньої галузі в Україні 95\% автодоріг знаходяться в неналежному транспортно-експлуатаційному стані, 40\% з них потребують негайної реконструкції і капітального ремонту, $65 \%$. За підрахунками експертів через одні тільки погані дороги держава щорічно втрачає близько 30 млрд. грн. ВВП [9].

Ціла низка проблем властива для залізничного транспорту. Термін доставки вагонів з вантажами за останні п'ять років знизився в два рази. Причина - в хронічній нестачі локомотивів у ПАТ «Укрзалізниця» і в зносі парку на 96\%. За 209 рік фрактична вартість транспортування зерна залізницею зросла на + 80-90\% (це сумарне підвищення з урахуван- ням зростання тарифру; вартості використання вагонів; застосування УЗ різних додаткових коефріцієнтів). Зростання вартості транспортування вантажів залізницею триватиме. Прийнятний для менеджменту УЗ горизонт підвищення тарисрів для вантажних перевезень від нинішнього рівня - в 2-2,5 рази [9].

Український морський транспортний комплекс ще не так давно складався 318 великих портів, обслуговуванням яких займались 3 пароплавства: Чорноморське, Азовське, Українське Дунайське. За останні десятиріччя ця сорера стикнулась 3 рядом труднощів: втрата українськими пароплавствами значної частини плавзасобів ( Чорноморське) через велику кількість нагромаджених боргів; різке скорочення обсягів перевезень транзитів через порти, значна кількість опинилась під загрозою закриття; непідконтрольність 8 кримських портів Україні; ускладнення роботи портів азовського узбережжя (в першу чергу, найбільшого з них - Маріуполя) вна-

Таблиця 1

Обсяг перевезених вантажів за видами транспорту протягом 2015-2019 років (тис. т)

\begin{tabular}{|c|c|c|c|c|c|c|c|}
\hline \multirow{2}{*}{ Рік } & \multicolumn{2}{|c|}{ Залізничний } & \multirow{2}{*}{ Морський } & Річковий & $\begin{array}{c}\text { Автомо- } \\
\text { більний }\end{array}$ & $\begin{array}{c}\text { Авіацій- } \\
\text { ний }\end{array}$ & $\begin{array}{c}\text { Трубопро- } \\
\text { відний }\end{array}$ \\
\hline 2015 & 294301,2 & 349994,8 & 3291,6 & 3155,5 & 1020604,0 & 69,1 & 97231,5 \\
\hline 2016 & 292104,7 & 343433,5 & 3032,5 & 3641,8 & 1085663,4 & 74,3 & 106729,2 \\
\hline 2017 & 277288,9 & 339550,5 & 2253,1 & 3640,2 & 1121673,6 & 82,8 & 114810,4 \\
\hline 2018 & 267639,1 & 322342,1 & 1892,0 & 3698,0 & 1205530,8 & 99,1 & 109418,2 \\
\hline 2019 & 262633,5 & 312938,9 & 2120,3 & 3990,2 & 1147049,6 & 92,6 & 112656,4 \\
\hline
\end{tabular}

Джерело: узагальнено за [9] 
слідок воєнних подій на Донбасі. Водні шляхи України значно скоротились через виведення 3 користування таких судноплавних річок, як Дністер, Прип'ять та її притоки, Сіверський Донець. Судноплавні дії по Дніпру скоротились у лічені рази - складають наразі мізерні обсяги. Великі вантажно-річкові порти знаходились у великих містах - Києві, Черкасах, Кременчуці, Дніпрі, Запоріжжі, Херсоні.

Для визначення фрорм і джерел ресурсозабезпечення, а також маштабів модернізації проведемо дослідження результатів інвестиційної активності в інфрраструктурній ссрері України. Так, в структурі здійснених інвестицій в масштабах національної економічної системи за 2020 рік, підприємства інсрраструктурної ссрери складають лише 10,8\% (в т.ч. транспорт 5,8\% та телекомунікації й інсрорма- ція - 5\%, інші - менше 1\%) (рис. 2). Такі тенденції зберігаються протягом 2010-2020 рр.

Діагностика об'єктності модернізації показала стійку тенденцію інвестування в матеріальні активи (в середньому по галузях 95\%) (рис. 3).

Аналіз рис. 3 показує техніко-технологічний характер модернізаційних змін на підприємствах інфрраструктурної сфрери, оскільки 33\% інвестицій - це капіталовкладення у технічне оновлення машин і обладнання, 23 \% - інженерні споруди.

В реаліях української економіки визначаючими векторність модернізації підприємств інфрраструктурної сфери є наступні закономірності:

- фррагментність технологічної структуризації національної економіки, викликана нерівномірністю розподілу державної інвестиційної підтримки та приватного капіталу;

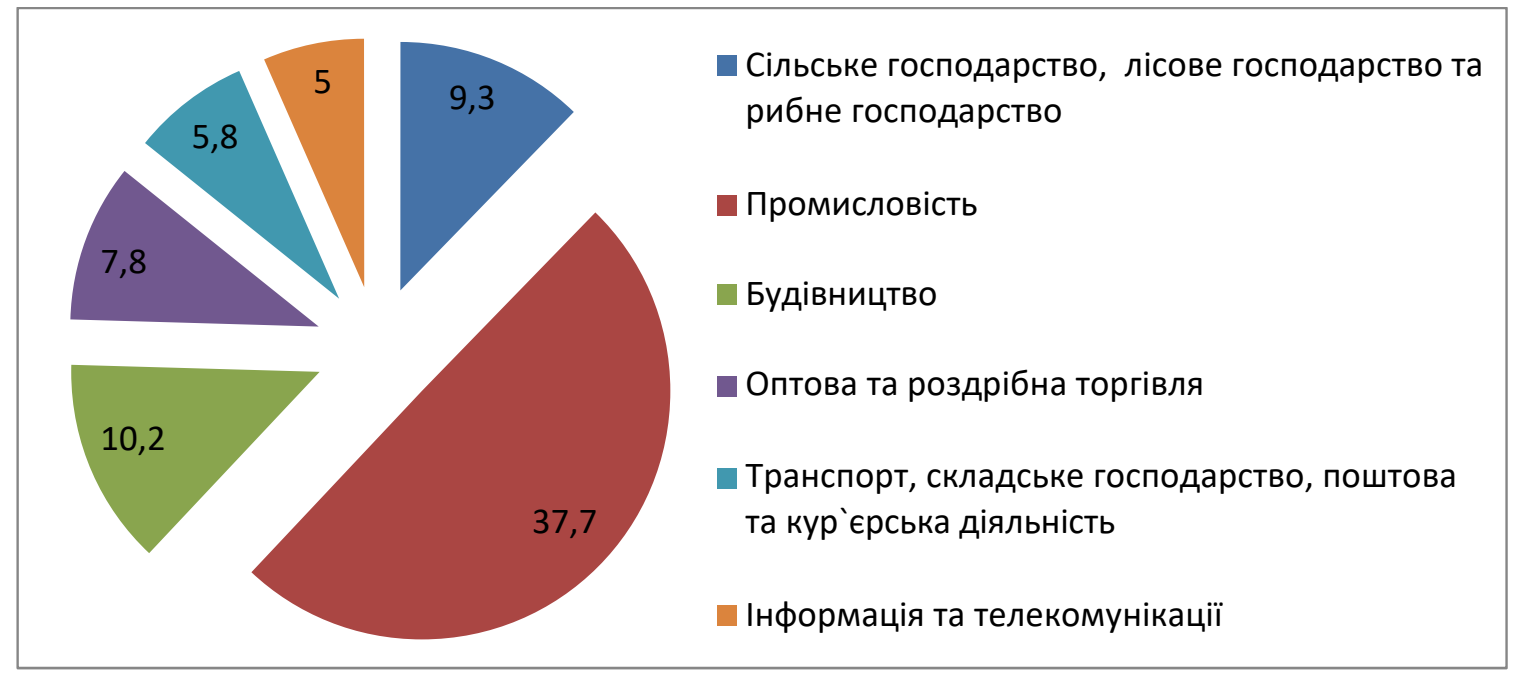

Рис. 2. Структура інвестування у модернізацію підприємств, у \%, 2020 ріці Джерело: побудовано авторами за [9]

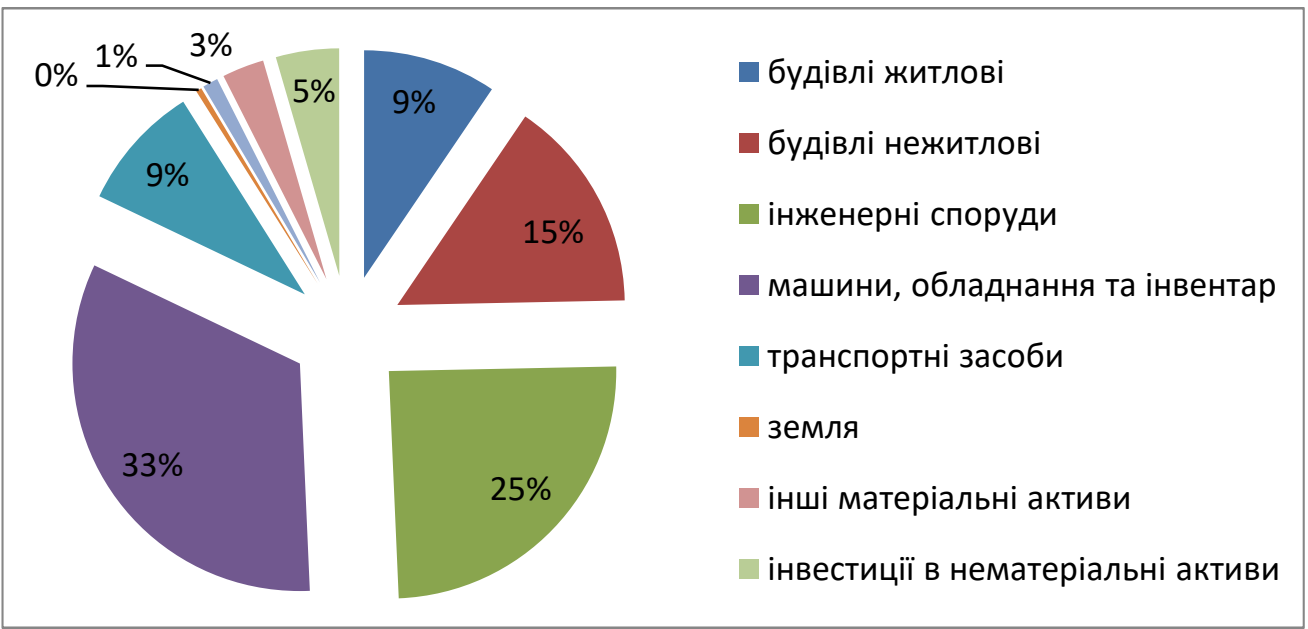

Рис. 3. Структура інвестиційної підтримки по об'єктах модернізації, $\%$, у 2020 році

Джерело: побудовано авторами за [9] 
- соціальні диспропорції між доходами в державному, приватному секторах, окремих галузях, що в сукупності провокують низьку купівельну спроможність та робочу міграцію кваліфікованих кадрів;

- реформування державного сектору економіки протягом останніх років залежить від зовнішнього фрінансування, при цьому міжнародна конкурентоздатність продукції національного виробництва у більшості $€$ невисокою та не забезпечує притоку фрінансового капіталу у вітчизняну економіку;

- запровадження електронного інституційного регулювання та дозвільного оформлення знижує рівень корупційності економіки, проте високі податкові ставки перешкоджають розвитку малого підприємництва;

- регіонально-територіальна реформа з однієї сторони провокує нерівномірність розподілу національних капіталів, робочої сили та технологій, а з іншої - сприяє активізації модернізаційних процесів та вмотивованості територіальних економічних утворень до залученості капіталів, модернізації інфрраструктури 3 метою розвитку комунікації із зовнішніми ринками (рис. 4).

Модернізація в описаних процесах має бути інструментарієм не лише технічного оновлення та нарощування прибутку, а й повинна комплексно і системно охоплювати всі сорери діяльності підприємства, адаптуватись та оперативно реагувати на зміни.

Описані умови інноваційно-інвестиційної діяльності підприємств свідчать, що в транспортній галузі залишаються невирішеними ряд проблем, які заважають її стратегічному розвитку та розширенню масштабів надання галузям економіки та населенню високоякісних транспортних послуг, гальмують відновлення економіки України [6-7]. Основним вектором для вирішення завдання мінімізації негативних впливів $€$ міжнародна інтеграція та нарощування відповідної конкурентоспроможності. Як такі можна виділити наднаціональні злиття процесів виробництва; розвиток зв'язків через спеціалізацію та кооперацію у виробництві; співробітництво у науково-технічній сорері; необхідність формування органів регулювання інтеграційного процесу, розробка спільної економічної стратегії і політики. У результаті, досягається більш висока ефективність економічної співпраці між країнами саме в умовах реалізації регіональної економічної інтеграції,оскільки через усунення бар'єрів та обмежень у тор-

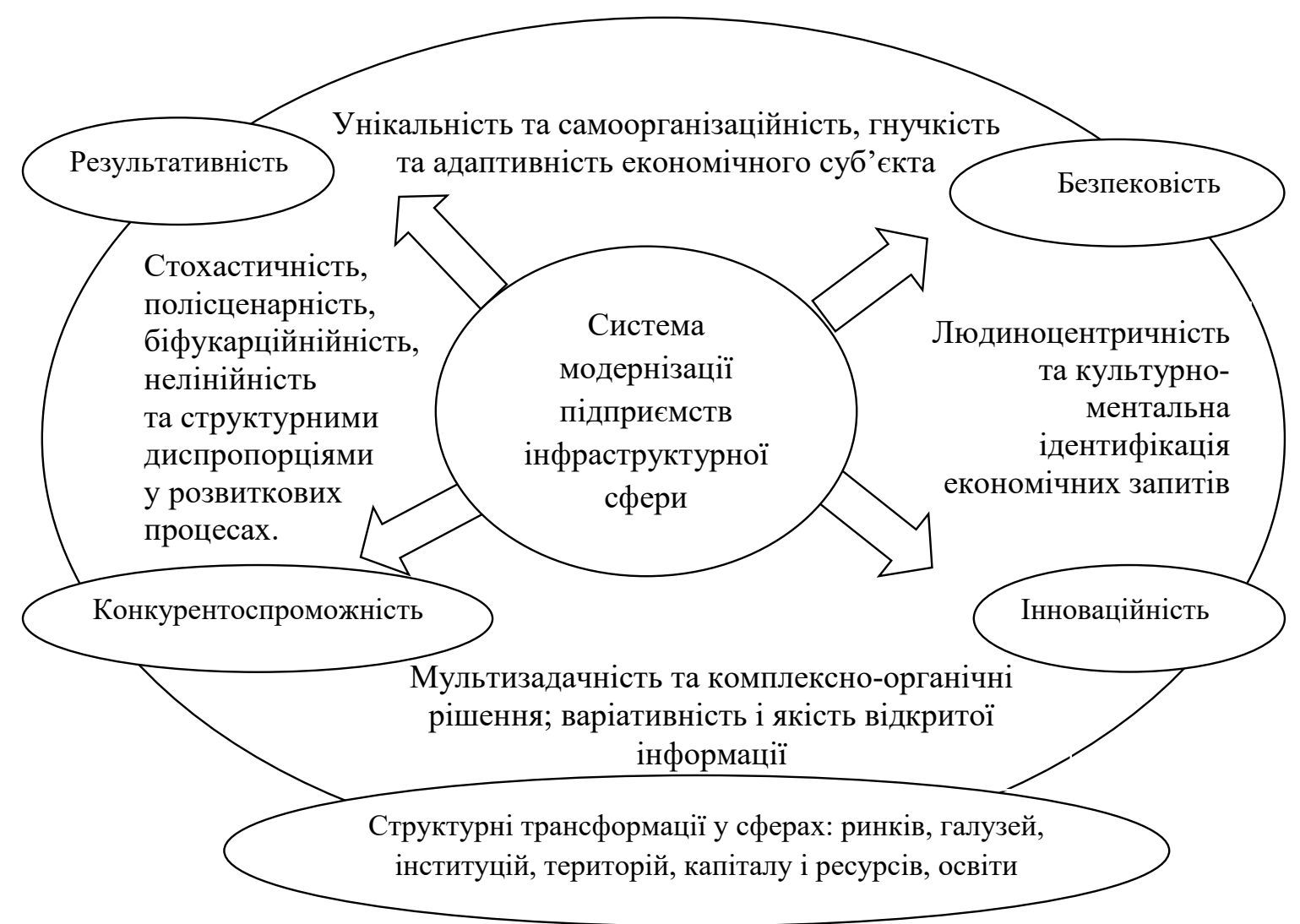

Рис. 4. Контур закономірностей модернізації підприємстві інфраструктурної сфери 
говельно-економічній ссрері, впровадження стандартизації та уніфрікації у виробничокомерційній сфері збільшуються товаро- i ресурсо- потоки, активізується підприємництво, що, у свою чергу, сприяє подальшому розвитку конкурентного механізму, розширенню ринку, отриманню додаткових переваг від економії на масштабах [2; 6].

Дослідивши низку праць, досліджень, аналізів, теоретичних і практичних робіт можна стверджувати, що розвиток інновацій й ефективне застосування інноваційних механізмів здатні вивести транспортний комплекс України із кризи на певну техніко-технологічну ступінь [5-6]. Обсяг фрінансування інновацій здійснюватиме позитивний вплив на процеси і терміни інноваційної реабілітації транспортного комплексу. Розробка і впровадження інновацій повинні стимулюватись значним інвестиційним забезпеченням, що виступає моделлю інноваційно-інвестиційного розвитку, перехід на яку обумовлений потребою пришвидшити техніко-технологічний розвиток. Впровадження інноваційних процесів щодо менеджменту підприємств враховуючи вимоги ринку послуг, галузеві й регіональні особливості, має стати пріоритетною задачею, щоб досягнути ефеективність й конкурентоспрожність діяльності транспортного комплексу держави.

Висновки. В контексті стратегічних пріоритетів України на шляху до нарощування конкурентоспроможності інсрраструктурної ссрери для забезпечення ефективності євроінтеграції актуальними $є$ дослідження умов інноваційноінвестиційного забезпечення модернізаційних процесів. Підприємства інфрраструктурної сорери в сучасних умовах стикаються із новими закономірностями в забезпеченні конкурентоспроможності та безпеки, фрормуванні якості послуг, інноваційності та результативності. Зазначені виклики свідчать, що в транспортній галузі залишаються невирішеними ряд проблем, які заважають її стратегічному розвитку, вирішення яких проектується масштабністю та ефективність інвестиційної підтримки модернізаційного процесу, а також доступністю нових інноваційних технологій.

\section{СПИСОК ВИКОРИСТАНИХ ДЖЕРЕЛ:}

1. Арефр'єва О.В. Конкурентоспроможність підприємств у міжнародному цисрровому просторі : монографія. Київ : ФОП Маслаков, 2019. 342 с.

2. Бутко М.П. Модернізація виробничої інфрраструктури машинобудівних підприємств. Ефективна економіка. 2015. № 3. URL: http://www.economy.nayka.com.ua/?op=1\&z=3860

3. Валінкевич Н.В. Теоретико-методологічні підходи до визначення сутності модернізації підприємств. Вісник Чернігівського державного технологічного університету. 2011. № 4(54). С. 34-41.

4. Петрович Й.М. Модернізація промислових підприємств як важлива передумова розвитку їх конкурентоспроможного потенціалу. Проблеми економіки і управління. Львів, 2015. № 815. С. 3-8.

5. Тульчинська С.О. Перспективи та домінанти розвитку інтелектуально-інноваційної системи регіонів України : монографія. Херсон : Вид-во «ПП Вишемирський В.С.», 2014. 210 с.

6. Кучерук Г.Ю., Тимощук О.М., Вовк О.М., Мельник О.В. Якість логістизації транспортних послуг: інвестиційний аспект : монограсрія. Київ : ТОВ «СІК ГРУП УКРАїНА», 2020. 184 с.

7. Ареср'єва О.В., Вовк О.М., Очеретяна С.О. Методичні засади діагностування результативності модернізації підприємств в контексті реалізації інноваційного потенціалу. Вісник Київського національного університету технологій та дизайну. 2020. Вип. 4(149). С. 8-16.

8. Сайт Верховної ради України. URL: http://zakon.rada.gov.ua

9. Сайт Державної служби статистики України. URL: http://www.ukrstat.gov.ua

\section{REFERENCES:}

1. Arefieva O.V. (2019) Konkurentospromozhnistj pidpryjemstv u mizhnarodnomu cyfrovomu [Competitiveness of enterprises in the international digital space]: monohrafiya [a monograph]. Kyiv: NAU. (in Ukrainian)

2. Butko M.P. (2015) Modernizatsiya vyrobnychoyi infrastruktury mashynobudivnykh pidpryyemstv [Modernization of industrial infrastructure at machine building plants]. Efektyvna ekonomika [Efficient economy], no. 3. Available at: http://www.economy.nayka.com.ua/?op=1\&z=3860 2006 (accessed 01 May 2021). (in Ukrainian)

3. Valinkevych N.V. (2011) Teoretykometodolohichni pidkhody do vyznachennya sutnosti modernizatsiyi pidpryyemstv [Theoretical and methodological approaches to determining the essence of enterprise modernization]. Visnyk Chernihivskoho derzhavnoho tekhnolohichnoho universytetu [Bulletin of Chernihiv State Technological University], vol. 4(54), pp. 34-41. (in Ukrainian) 
4. Petrovych Y.M. (2015) Modernizatsiya promyslovykh pidpryyemstv yak vazhlyva peredumova rozvytku yikh konkurentospromozhnoho potentsialu [Modernization of industrial enterprises as an important prerequisite for the development of their competitive potential]. Problemy ekonomiky i upravlinnia [Problems of economics and management], no. 815, pp. 3-8. (in Ukrainian)

5. Tulchynska S.O. (2014) Perspektyvy ta dominanty rozvytku intelektualno-innovatsiinoi systemy rehioniv Ukrainy [Perspectives and dominants of the development of the intellectual and innovative system of the regions of Ukraine]: monohrafiya [a monograph]. Kherson: PP "Vishemirsky". (in Ukrainian)

6. Kucheruk H.Yu., Tymoschuk O.M., Vovk O.M. and Melnyk O.V. (2020) Yakist lohistyzatsii transportnykh posluh: investytsijnyj aspect [Quality of logistics of transport services: investment aspect]: monohrafiya [a monograph]. Kyiv: TOV «SIK HRUP UKRAYINA». (in Ukrainian)

7. Arefieva O.V., Vovk O.M. and Ocheretyana S.M. (2020) Metodychni zasady diahnostuvannya rezultatyvnosti modernizatsiyi pidpryyemstv $\vee$ konteksti realizatsiyi innovatsiynoho potentsialu [Methodological framework for assessing the enterprise modernization performance in the context of realizing its innovative potential]. Visnyk Kyivskoho natsionalnoho universytetu tekhnolohiy ta dyzaynu [Bulletin of the Kyiv National University of Technologies and Design], no. 4(149), pp. 8-16. (in Ukrainian)

8. Sayt Verkhovnoyi rady Ukrayiny. Available at: http://zakon.rada.gov.ua

9. Sayt Derzhavnoyi sluzhby statystyky Ukrayiny. Available at: http://www.ukrstat.gov.ua 